\title{
Influence of Nano Additives on Protective Coatings for Oil Pipe Lines of Oman
}

\author{
Muhammad Mumtaz Mirza, Elansezhian Rasu, and Anjali Desilva
}

\begin{abstract}
The paper presents, analyzes and comments on the findings for different type of nano-additives used in painted coatings against the corrosion behavior for steel pipe lines, used in petroleum industry of Oman. The examination for the rate of corrosion in low alloy steel pipelines included a range of coated samples that includes organic paint, metallic paint, Aluminum, Zinc and electroless ones. After the samples were coated, the surface roughness was checked and the coating thickness maintained. For corrosion rate analysis and the evaluation of each coating's life period, a number of test including atmospheric exposure test, dry and wet test and potentiodynamic test were conducted. In order to analyze the surface behavior of coatings, characterization was performed with SEM-scanning electron microscope that later supported with hardness test results. The performance analysis of several coatings investigates that, mixture of nano $\mathrm{Al}_{2} \mathrm{O}_{3}$ additive with Aluminum paint gives the best result against corrosion and presented good surface performance in comparison with other samples.
\end{abstract}

Index Terms-Electroless, coatings, corrosion, nano additives, $\mathrm{Al}_{2} \mathbf{O}_{3}$.

\section{INTRODUCTION}

The corrosion of pipelines is one of the major problems faced by the engineers and technicians in the oil field. The annual cost of corrosion worldwide is over three per cent of the world's GDP and is around \$2.2 trillion as per the National Association of Corrosion Engineers. Moreover, accidents caused by corroded structures can lead to huge safety concerns, loss of life, and resources [1].

Corrosion is the gradual destruction of materials (usually metals) by chemical reaction with its environment. Many structural alloys corrode merely from exposure to moisture in air, but the process can be strongly affected by exposure to certain substances. Corrosion can be concentrated locally to form a pit or crack, or it can extend across a wide area more or less uniformly corroding the surface. Because corrosion is a diffusion-controlled process, it occurs on exposed surfaces but methods such as passivation and chromate conversion can increase a material's corrosion resistance and therefore reduce such exposure. However, some corrosion mechanisms are less visible and less predictable [2]

EN - Electroless nickel plating is an auto-catalytic reaction

Manuscript received August 19, 2015; revised October 30, 2015.

Muhammad Mumtaz Mirza and Elansezhian Rasu are with the Department of Mechanical and Industrial Engineering, Caledonian College of Engineering, Seeb, CPO 111, Sultanate of Oman (e-mail: mumtazyousafi2000@gmail.com).

Anjali Desilva is with the School of Engineering \& Built Environment Glasgow Caledonian University, Glasgow, Scotland, UK. used to deposit a coating of nickel on a substrate. Unlike electro plating, it is not necessary to pass an electric current through the solution to form a deposit. This plating technique prevents corrosion as well as wear and develops uniform coating thickness [3].

The EN plating of metallic nickel from aqueous solution in the presence of hypoph osphite was first noted by Wurtz in 1844 [4]. In 1911, Roux reported that metal was inevitably precipitated in the powder form; however these works were not in practical applications [5]. In its early stage, progress in the field remained slow until World War II. In 1946, Brenner and Riddell developed a process for plating the inner walls of tubes with nickel-tungsten alloy, derived from the citrate based bath using an insoluble anode, which brought out the unusual reducing properties of hypophosphite [6]. Initially, the co-deposition of particles was carried out for electrodepositing Ni-Cr by Odekerken, during the year 1966 [7]. In this study, finely powdered particles such as aluminum oxide and polyvinyl chloride (PVC) resin were distributed within a metallic matrix in an intermediate layer. The first commercial application of their work used the electroless $\mathrm{Ni}-\mathrm{SiC}$ coatings on the Wankel internal combustion engine in 1981[8].

Fusion-bonded epoxy (FBE) and a three-layer polyolefin (3LPO) (polyethylene or polypropylene (PP)) are currently the most widely used external anti-corrosion coating systems available in the international market [9].

A new technique of protection coating is presented with sufficient results in Electroless Nickel EN-P deposition with $\mathrm{Al}_{2} \mathrm{O}_{3}$ as nano additive. In this method, coating is done uniformly with equal thickness to the entire surface [10], [11].

\section{EXPERIMENTAL SETUP}

\section{A. Collection of Samples}

The samples considered in this study are low alloy steel taken from the local oil and gas industry of Oman. A total numbers of nine samples were coated as presented in Table I.

TABLE I: COATING TYPES

\begin{tabular}{|c|c|}
\hline Coating Type & Qty/size of sample \\
\hline Aluminum paint with nano $\mathrm{ZnO}$ & $1\left(50 \times 50 \times 7 \mathrm{~mm}^{3}\right)$ \\
\hline Zinc Paint with nano $\mathrm{ZnO}$ & $1\left(50 \times 50 \times 7 \mathrm{~mm}^{3}\right)$ \\
\hline Organic Paint with nano $\mathrm{ZnO}$ & $1\left(50 \times 50 \times 7 \mathrm{~mm}^{3}\right)$ \\
\hline Organic Paint with nano $\mathrm{CuO}$ & $1\left(50 \times 50 \times 7 \mathrm{~mm}^{3}\right)$ \\
\hline Aluminum paint with nano $\mathrm{CuO}$ & $1\left(50 \times 50 \times 7 \mathrm{~mm}^{3}\right)$ \\
\hline Zinc Paint with nano $\mathrm{CuO}$ & $1\left(50 \times 50 \times 7 \mathrm{~mm}^{3}\right)$ \\
\hline Organic Paint with nano $\mathrm{Al}_{2} \mathrm{O}_{3}$ & $1\left(50 \times 50 \times 7 \mathrm{~mm}^{3}\right)$ \\
\hline Zinc Paint with nano $\mathrm{Al}_{2} \mathrm{O}_{3}$ & $1\left(50 \times 50 \times 7 \mathrm{~mm}^{3}\right)$ \\
\hline Aluminum Paint with nano $\mathrm{Al}_{2} \mathrm{O}_{3}$ & $1\left(50 \times 50 \times 7 \mathrm{~mm}^{3}\right)$ \\
\hline
\end{tabular}




\section{B. Sample Preparation}

Nine samples were primary polished with wet 400, 600, 800 and 2000 grit $\mathrm{SiC}$ paper. For proper adhesion, the surface of each sample was cleaned with distilled water. Later, Acetone was used for further cleaning followed by rinsing with distilled water. Moreover, ultrasonic cleaning was done for three minutes with Methanol again followed by washing with distilled water. For primer base, the samples were coated with primer paint (Red Oxide).Each sample was then painted with $0.50 \mathrm{ml}$ paint of organic, zinc and aluminum paint separately. These samples were then used to mix with $0.5 \mathrm{gms}$ of nano additives of $\mathrm{ZnO}, \mathrm{CuO}$ and $\mathrm{Al}_{2} \mathrm{O}_{3}$ separately. The size of nano additives has particle size of $50 \mathrm{~nm}$ which were used in the coating. Paint and nano additives were mixed and put to stir for 2 hours (see Fig. 1).

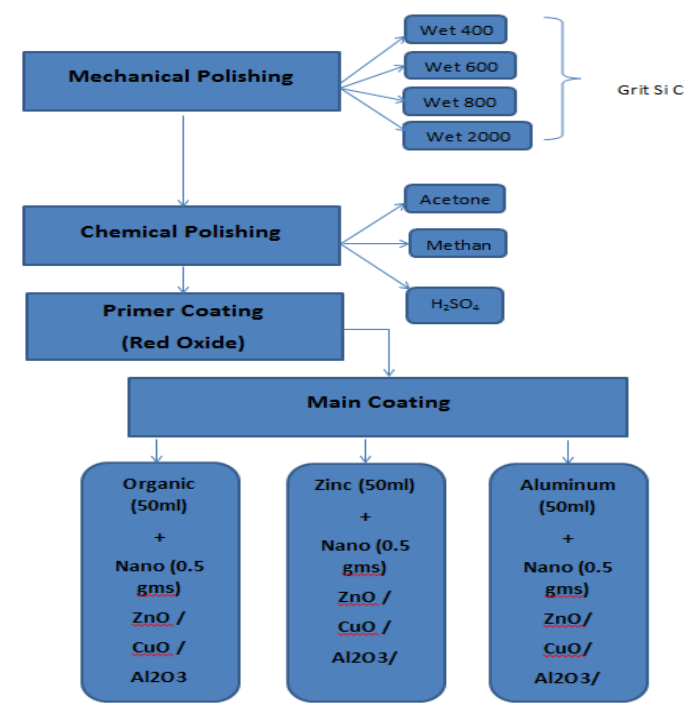

Fig. 1. Sample preparation.

\begin{tabular}{|l|l|}
\hline \multicolumn{1}{|c|}{ Particulars } & Composition \\
\hline Nickel Chloride & $6 \mathrm{gm} / 25 \mathrm{ml}$ bath \\
\hline Sodium hypo-phosphate & $8 \mathrm{gm} / 25 \mathrm{ml}$ \\
\hline Sodium Acetate & $5 \mathrm{gm} / 25 \mathrm{ml}$ \\
\hline Ammonium Chloride & $10 \mathrm{gm} / 25 \mathrm{ml}$ \\
\hline Bath volume & $200 \mathrm{ml}$ \\
\hline PH & $9-10$ \\
\hline Temperature & $85 \pm 1^{\circ} \mathrm{C}$ \\
\hline
\end{tabular}

Fig. 2. Chemical composition for EN-P bath.

In preparing EN-P coatings, same procedure of cleaning was followed for low alloy steel samples of size $50 \times 50 \times 7$ $\mathrm{mm}^{3}$. The coating bath consists of the chemical composition as shown in Fig. 2. Nano additives of $\mathrm{Al}_{2} \mathrm{O}_{3}(0.2 \mathrm{~g})$, and $\mathrm{ZnO}$ $(0.2 \mathrm{~g})$ were mixed with the chemicals prepared for the coating. Process parameters such as $\mathrm{pH}$, temperature and effect of surfactant i.e. Cetyl Trimethyl Ammonium Bromide (CTAB) concentrations were varied. The $\mathrm{pH}$ level was adjusted by addition of Ammonia. It was noticed that for $\mathrm{pH}$ value of 9-10, temperature was maintained at $85^{\circ} \mathrm{C}$. Sodium lauryl sulfate (SLS-1.2gpl) was used for better EN-P coating. The electrolyte was heated directly by an electrically heated water bath whose temperature was regulated by PID controller. The coating was prepared for a period of $1 \mathrm{hr}$ with total volume of the coating bath restricted to $200 \mathrm{ml}$.Coated samples are shown in Fig. 3-Fig. 5.

\section{Sample Preparation for Atmospheric Exposure Test}

Samples were set out in three categories. The first Batch of samples had specimen size of $50 \times 50 \times 7 \mathrm{~mm}^{3}$ as shown in Fig. 3-Fig. 5. Each sample was marked, weighted and recorded. The samples were exposed to the atmosphere for 60 days. The test carried out in ambient condition of Muscat Oman, which was dry with ambient temperature varies from 35 to $46{ }^{\circ} \mathrm{C}$, average relative humidity of 60 to $65 \%$ and average wind speed of $3 \mathrm{~m} / \mathrm{s}$.

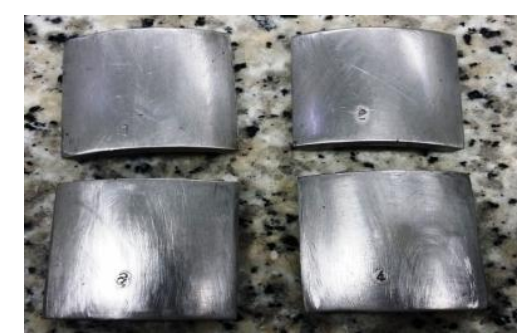

Fig. 3. Samples after mechanical \& chemical polishing.

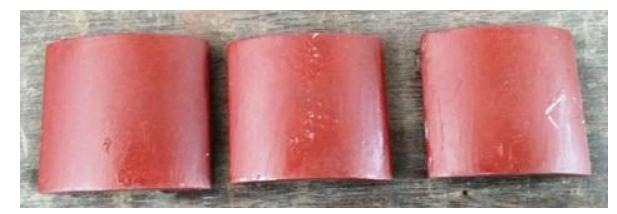

Fig. 4. Samples after primer coating.

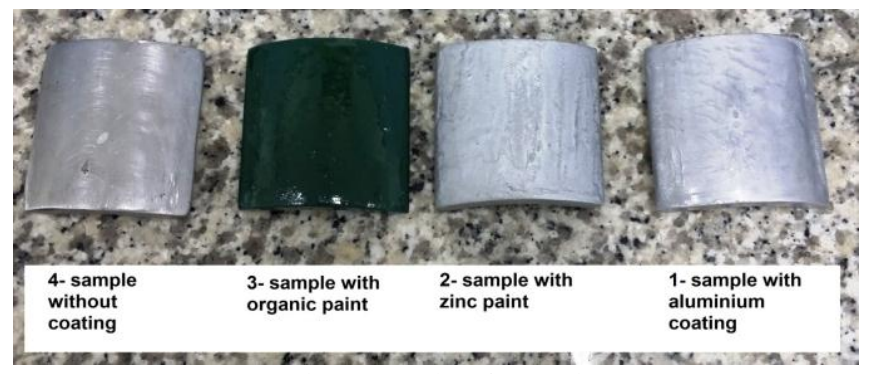

Fig. 5. Samples after coating.

\section{Sample Preparation for Dry/Wet Test}

Two samples of size $20 \times 20 \times 7 \mathrm{~mm}^{3}$ were also prepared for the dry/wet test as shown in Fig. 6 and Fig. 7. The sample size was configured as per the size allowed by the dry/wet test equipment.

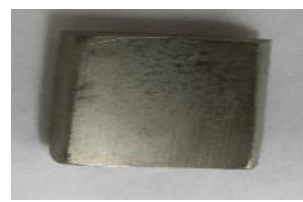

Fig. 6. Sample after mechanical and chemical polishing.

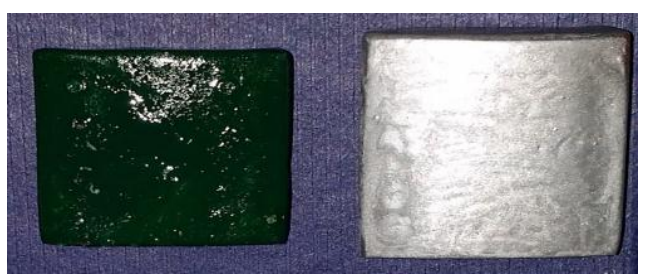

Fig. 7. Sample after coating. 


\section{EXPERIMENTAL PROCEDURE}

\section{A. Surface Roughness Test}

In order to evaluate further, initially the samples coating surface roughness were measured. The investigation was carried out by using Mitutoyo surface measurement equipment. Results are shown in Fig. 8 to $10 . \mathrm{CuO}$ with $\mathrm{Al}$ paint gives the least value of $R_{z} 3.77 \mu \mathrm{m}$ and maximum surface roughness was for $\mathrm{Al}_{2} \mathrm{O}_{3}$ with organic paint of $R_{z} 9.92$ $\mu \mathrm{m}$.

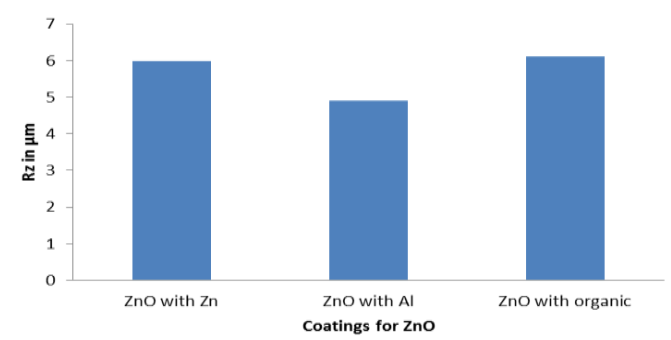

Fig. 8. Surface roughness for $\mathrm{ZnO}$

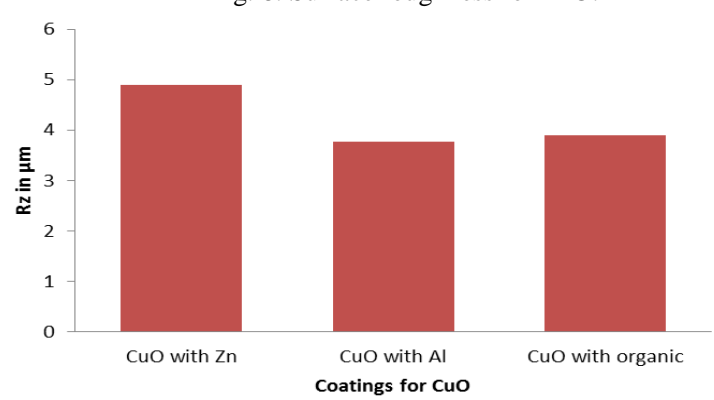

Fig. 9. Surface roughness for $\mathrm{CuO}$

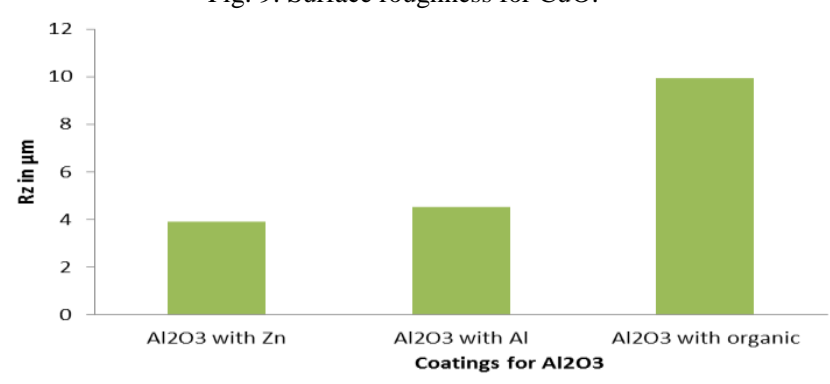

Fig. 10. Surface roughness for $\mathrm{Al}_{2} \mathrm{O}_{3}$.

\section{B. Atmospheric Exposure Test}

Atmospheric test was the first experiment to be conducted for an exposition period of 60 days with ambient conditions as stated above. Nine different coatings were developed i.e. organic paint, aluminum paint, zinc paint with nano additives. Notations used in experimentation are given below in Table II.

TABLE II: SAMPLE NOTATIONS

\begin{tabular}{|l|l|}
\hline $\mathrm{ZnO}+$ Organic paint coating & $(\mathrm{Z}-\mathrm{O})$ \\
\hline $\mathrm{ZnO}+$ Aluminum paint Coating & $(\mathrm{Z}-\mathrm{A})$ \\
\hline $\mathrm{ZnO}+$ Zinc paint Coating & $(\mathrm{z}-\mathrm{Z})$ \\
\hline $\mathrm{CuO}+$ Organic paint coating & $(\mathrm{C}-\mathrm{O})$ \\
\hline $\mathrm{Al}_{2} \mathrm{O}_{3}+$ Zinc paint coating & $(\mathrm{A}-\mathrm{Z})$ \\
\hline $\mathrm{CuO}+$ Aluminum paint coating & $(\mathrm{C}-\mathrm{A})$ \\
\hline $\mathrm{CuO}+$ Zinc paint coating & $(\mathrm{C}-\mathrm{Z})$ \\
\hline $\mathrm{Al}_{2} \mathrm{O}_{3}+$ Organic paint coating & $(\mathrm{A}-\mathrm{O})$ \\
\hline $\mathrm{Al}_{2} \mathrm{O}_{3}+$ Aluminum paint coating & $(\mathrm{A}-\mathrm{a})$ \\
\hline
\end{tabular}

TABLE III: EXPOSURE TIME

\begin{tabular}{|l|l|l|l|l|l|l|l|l|l|l|l|l|}
\hline Samples & \multicolumn{7}{|c|}{ Period of Exposure (Weeks) } \\
\hline $\begin{array}{l}\text { Coated } \\
\text { Samples }\end{array}$ & $\mathbf{1}$ & $\mathbf{2}$ & $\mathbf{3}$ & $\mathbf{4}$ & $\mathbf{5}$ & $\mathbf{6}$ & $\mathbf{7}$ & $\mathbf{8}$ & $\mathbf{9}$ & $\mathbf{1 0}$ & $\mathbf{1 1}$ & $\mathbf{1 2}$ \\
\hline (Z-O) & & & & & & & & & $\mathbf{x}$ & $\mathbf{x}$ & $\mathbf{x}$ & $\mathbf{x}$ \\
\hline (Z-A) & & & & & & & & & & $\mathbf{x}$ & $\mathbf{x}$ & $\mathbf{x}$ \\
\hline (Z-Z) & & & & & & & & & $\mathbf{x}$ & $\mathbf{x}$ & $\mathbf{x}$ & $\mathbf{x}$ \\
\hline (C-O) & & & & & & & & & & $\mathbf{x}$ & $\mathbf{x}$ & $\mathbf{x}$ \\
\hline (C-A) & & & & & & & & & & $\mathbf{x}$ & $\mathbf{x}$ & $\mathbf{x}$ \\
\hline (C-Z) & & & & & & & & & & $\mathbf{x}$ & $\mathbf{x}$ & $\mathbf{x}$ \\
\hline (A-O) & & & & & & & & & & & $\mathbf{x}$ & $\mathbf{x}$ \\
\hline (A-a) & & & & & & & & & & & & $\mathbf{x}$ \\
\hline (A-Z) & & & & & & & & & & & $\mathbf{x}$ & $\mathbf{x}$ \\
\hline
\end{tabular}

Table III indicates that $\mathrm{Al}_{2} \mathrm{O}_{3}$ with Aluminum paint (A-a) coating provides maximum resistance to corrosion where as $\mathrm{ZnO}$ with $\mathrm{Zinc}$ coating $(\mathrm{Z}-\mathrm{z})$ and $\mathrm{ZnO}$ with organic paint (Z-O) gives the least. To calculate the corrosion rate of the samples following formula was used [12]:

Corrosion rate in millimeter per year

$$
\text { mmpy }=87.6(\mathrm{~W} / \mathrm{DAT})
$$

where

mmpy $=$ Corrosion rate in millimeter per year.

$W=$ Weight loss in grams

$D=$ Density in gms $/ \mathrm{cm}^{3}$

$A=$ Area in $\mathrm{cm}^{2}$

$T=$ Time in hours.

TABLE IV: CORROSION RATE OF SAMPLES

\begin{tabular}{|l|l|l|l|l|l|l|l|}
\hline Sample & $\begin{array}{l}\text { Initial } \\
\text { weight } \\
(\mathrm{g})\end{array}$ & $\begin{array}{l}\text { Final } \\
\text { weight } \\
(\mathrm{g})\end{array}$ & $\begin{array}{l}\text { Weight } \\
\text { loss } \\
(\mathrm{g})\end{array}$ & $\begin{array}{l}\text { Area } \\
\left(\mathrm{cm}^{2}\right.\end{array}$ & $\begin{array}{l}\text { Tim } \\
\mathrm{e} \\
(\mathrm{hr})\end{array}$ & $\begin{array}{l}\text { Density } \\
\left(\mathrm{g} \mathrm{cm}^{3}\right)\end{array}$ & $\begin{array}{l}\text { Corrosion } \\
\text { rate } \\
(\mathrm{mmpy})\end{array}$ \\
\hline$(\mathrm{Z}-\mathrm{O})$ & 121.49 & 120.69 & 0.8 & 64 & 720 & 7.874 & 7.6080 \\
\hline (Z-A) & 116.65 & 115.86 & 0.79 & 64 & 720 & 7.874 & 7.5129 \\
\hline$(\mathrm{Z}-\mathrm{z})$ & 120.28 & 119.39 & 0.89 & 64 & 720 & 7.874 & 8.4639 \\
\hline (C-O) & 121.30 & 120.7 & 0.6 & 64 & 720 & 7.874 & 5.7060 \\
\hline (C-A) & 120.32 & 119.76 & 0.56 & 64 & 720 & 7.874 & 5.3256 \\
\hline$($ C-Z $)$ & 118.74 & 118.06 & 0.68 & 64 & 720 & 7.874 & 6.4668 \\
\hline (A-O) & 116.31 & 116.11 & 0.2 & 64 & 720 & 7.874 & 1.9020 \\
\hline (A-a) & 125.27 & 125.09 & 0.18 & 64 & 720 & 7.874 & 1.7118 \\
\hline (A-Z) & 119.28 & 119.08 & 0.2 & 64 & 720 & 7.874 & 1.9020 \\
\hline
\end{tabular}

It is indicative from Table IV that $\mathrm{Al}_{2} \mathrm{O}_{3}$ with Aluminum paint (A-a) was having the lowest corrosion rate response when compared with the rest.

\section{Potentiodynamic Test}

The Potentiodynamic test is a type of direct current (DC) Test. During this test the potential at a selected (usually anodic) voltage was maintained and measured the current as a function of time. $\mathrm{Ag} / \mathrm{AgCl}$ in saturated $\mathrm{KCl}$ is used as a reference electrode. Three tests were conducted for samples without coating, EN-P with $\mathrm{ZnO}$ and with $\mathrm{Al}_{2} \mathrm{O}_{3}$.

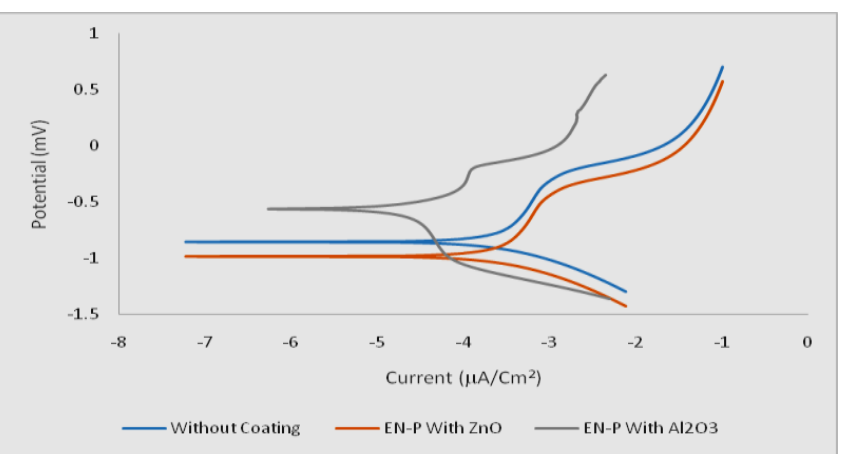

Fig. 11. Tafel graph for coatings. 
To calculate the corrosion rate using the current from metal loss, the following formula is used as shown in Equation (2) [13]:

where:

$$
m m / y=3.27 \times 10^{-3} \times I_{\text {corr }} \times W / \rho
$$

$W=$ Equivalent weight in grams for low alloy steel.

$\rho=$ Metal density for low alloy steel in $\mathrm{g} / \mathrm{cm}^{3}$.

$I_{\text {corr }}=$ Current from Tafel graph in $\mu \mathrm{A} / \mathrm{cm}^{2}$ (see Fig. 11).

TABLE V: CORROSION RATE IN MMPY

\begin{tabular}{|c|c|c|c|l|}
\hline Sample & $\begin{array}{l}I_{\text {corr }}= \\
\text { Current } \\
\mu \mathrm{A} / \mathrm{cm}^{2}\end{array}$ & $\begin{array}{l}\text { E.W } \\
\mathrm{gms}\end{array}$ & $\begin{array}{l}\text { Density } \\
\left(\mathrm{g} / \mathrm{cm}^{3}\right)\end{array}$ & $\begin{array}{l}\text { Corrosion } \\
\text { rate-mmpy }\end{array}$ \\
\hline Without coating & 7.25 & 27.92 & 7.874 & 0.0840 \\
\hline EN-P with ZnO & 7.20 & 27.92 & 7.874 & 0.0834 \\
\hline $\begin{array}{c}\text { EN-P With } \\
\mathrm{Al}_{2} \mathrm{O}_{3}\end{array}$ & 6.20 & 27.92 & 7.874 & 0.0718 \\
\hline
\end{tabular}

The test result showed Tafel extrapolation curve for each coated sample. Current calculated for each sample was then used in calculating the corrosion rate using Eq. (2). Calculations are shown in Table V. En-P with $\mathrm{AL}_{2} \mathrm{O}_{3}$ stated minimum corrosion rate of 0.0718 and without coating indicates maximum corrosion rate of $0.0840 \mathrm{mmpy}$.

\section{Dry/Wet Test}

For accelerated corrosion, dry/wet test was conducted. The basic idea of the test was to have the samples dipped in the filtered sea water and dry it to the atmospheric air. Filtered from impurities, the sea water was used with $\mathrm{pH}$ value of 7.6. The filtered sea water was poured in to small glass made chambers and nine samples were examined as indicated in Table II. Samples were dipped in the filtered sea water for 16 hours and dried in the atmospheric air for 8 hours. Test was conducted for 14 days, results are shown in Table VI.

TABLE VI: CORROSION RATE OF SAMPLES

\begin{tabular}{|l|r|r|r|r|r|r|r|}
\hline Sample & $\begin{array}{l}\text { Initial } \\
\text { weight } \\
(\mathrm{g})\end{array}$ & $\begin{array}{l}\text { Final } \\
\text { weight } \\
(\mathrm{g})\end{array}$ & $\begin{array}{l}\text { Weight } \\
\text { loss (g) }\end{array}$ & Area $\left(\mathrm{cm}^{2}\right)$ & $\begin{array}{l}\text { Time } \\
(\mathrm{hr})\end{array}$ & $\begin{array}{l}\text { Density } \\
\left(\mathrm{g} / \mathrm{cm}^{3}\right)\end{array}$ & $\begin{array}{l}\text { Corrosion } \\
\text { rate } \\
(\mathrm{mmpy})\end{array}$ \\
\hline$(\mathrm{Z}-\mathrm{O})$ & 123 & 120.7 & 2.31 & 13.6 & 336 & 7.874 & 5.62 \\
\hline$(\mathrm{Z}-\mathrm{A})$ & 117 & 115.9 & 1.14 & 13.6 & 336 & 7.874 & 2.78 \\
\hline$(\mathrm{Z}-\mathrm{z})$ & 121 & 119.4 & 1.61 & 13.6 & 336 & 7.874 & 3.92 \\
\hline$(\mathrm{C}-\mathrm{O})$ & 121 & 120.7 & 0.3 & 13.6 & 336 & 7.874 & 0.73 \\
\hline$(\mathrm{C}-\mathrm{A})$ & 122 & 119.8 & 2.24 & 13.6 & 336 & 7.874 & 5.45 \\
\hline$(\mathrm{C}-\mathrm{Z})$ & 119 & 118.1 & 0.94 & 13.6 & 336 & 7.874 & 2.29 \\
\hline$(\mathrm{A}-\mathrm{O})$ & 116.5 & 116.1 & 0.39 & 13.6 & 336 & 7.874 & 0.95 \\
\hline$(\mathrm{A}-\mathrm{a})$ & 125.23 & 125.1 & 0.14 & 13.6 & 336 & 7.874 & 0.34 \\
\hline$(\mathrm{A}-\mathrm{Z})$ & 119.29 & 119.1 & 0.21 & 13.6 & 336 & 7.874 & 0.51 \\
\hline
\end{tabular}

The results indicated that the sample coated with nano additives of $\mathrm{Al}_{2} \mathrm{O}_{3}$ possessed strong corrosion resistance with value of 0.34 mmpy. Moreover, the highest rate of corrosion was with (Z-O) paint of $5.62 \mathrm{mmpy}$.

\section{CHARACTERIZATION}

\section{A. Surface Morphology}

Surface morphology of the samples was studied to analyze the surface of the coatings through SEM (Scanning Electron
Microscope). Images of the six samples are shown in Fig. 12. Aluminum, zinc and organic coatings indicate the corrosion in different areas. It is also observed that organic coating was affected more than the zinc and the aluminum. The image of Electroless nickel depicts that the nickel was deposited on the surface of the sample. Image of EN-P with addition of $\mathrm{Al}_{2} \mathrm{O}_{3}$ demonstrates the deposition of Nickel with small particles of Nano $\mathrm{Al}_{2} \mathrm{O}_{3}$ that contributes better resistance than sample coated with EN-P only. Moreover, the surface area of the sample without any coating can be seen as completely corroded.
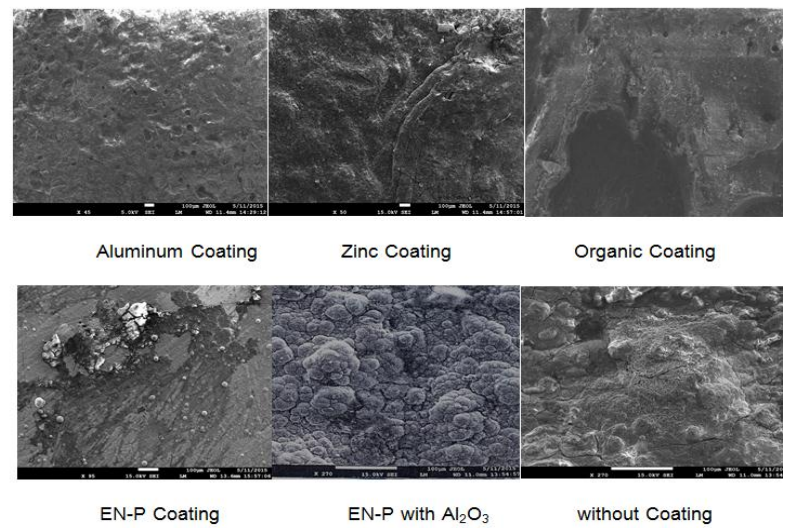

Fig. 12. Images of samples through SEM.

\section{B. Hardness Testing}

Hardness testing for coatings was done through Vickers hardness test. The weight used was $5 \mathrm{~kg}$ for 10 seconds for all the samples (see Fig. 13 \& Fig. 14).
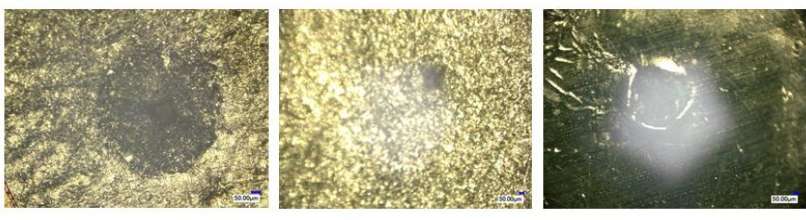

1- Aluminum Coating

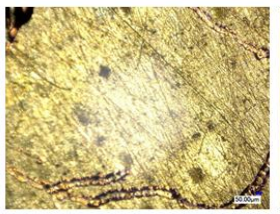

2-Zinc Coating

3-Organic Coating

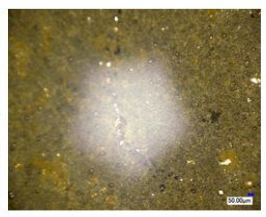

5-EN-P with $\mathrm{Al}_{2} \mathrm{O}$

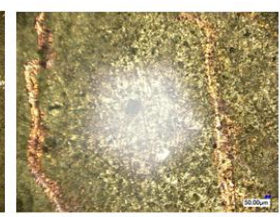

6-Without Coating

Fig. 13. Samples after indentation

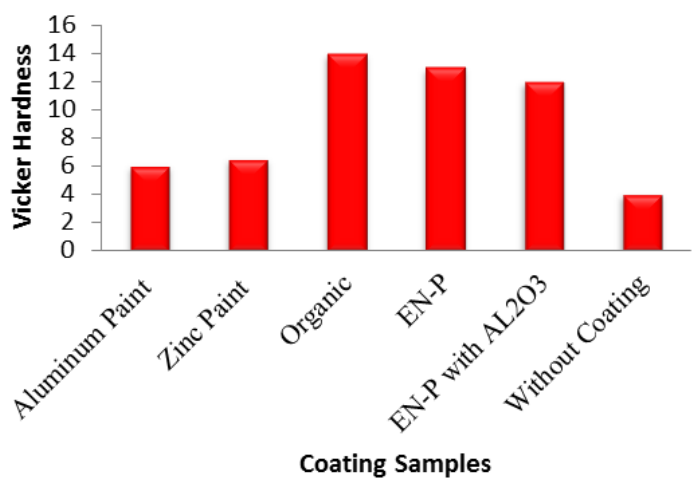

Fig. 14. Samples hardness.

The micro radial cracks were examined on sample EN-P with $\mathrm{Al}_{2} \mathrm{O}_{3}$ and a lesser crack generation was observed as 
compared with the other samples. It also observed that the sample would not be peeled off as easily compared to the rest of the batch. It also illustrated that the adhesion process between the deposit and substrate was rather good [14].

\section{CONCLUSION}

Corrosion is a natural occurring phenomena and although cannot be eliminated from the metals. It can be isolated from the reaction by applying coating to cover the metal from exposure or can be coated with strong volunteer component as coated layer from the base metal to be protected [15]. Different coating behaviors on the external surface of low alloy steel pipe line used in Oman oil and gas industry are examined. To confirm the corrosion rate for different coating behaviors, test were conducted like atmospheric exposure test, dry/wet test and potentiodynamic test. Similarly, SEM and hardness test were also performed to confirm the characterization. The following results are drawn:

1) Atmospheric exposure test was conducted for the said materials in specific ambient conditions. The highest corrosion rate was investigated for Z-z for 8.46 mmpy and lowest corrosion rate was observed for A-a i.e. $1.7118 \mathrm{mmpy}$. Therefore the coating paint group is resulted with highly resistance to the corrosion occurs i.e. aluminum paint followed by organic paint and then Zinc paint.

2) The samples coated with EN-P Electroless nickelPhosphorus. Two types of coatings were used by EN-P, one without nano additives particles and other with the addition of nano additives of $\mathrm{Al}_{2} \mathrm{O}_{3}$. Dry/wet test was conducted. The sample coated with EN-P with nano additives of $\mathrm{Al}_{2} \mathrm{O}_{3}$ (A-a) has promising corrosion resistance result of 0.34 mmpy. Moreover, the highest rate of corrosion in terms of the sample coated with Z-O has 5.62 mmpy.

3) Potentiodynamic test was also concluded for the said samples. The minimum corrosion current and potential was for the sample coated with EN-P with nano $\mathrm{Al}_{2} \mathrm{O}_{3}$ coating whereas the maximum was for the uncoated sample.

4) For accelerated corrosion a dry/wet test was conducted. The result established that the sample coated with nano additives of $\mathrm{Al}_{2} \mathrm{O}_{3}$ has promising corrosion resistance result of 0.34 mmpy. Moreover, the highest rate of corrosion in terms of the sample coated is with the Z-O of $5.62 \mathrm{mmpy}$.

5) Surface morphology of the samples was studied through SEM to analyze the microstructure of the coatings. The image of Electroless nickel depicts that the nickel was deposed on the surface of the sample. Image of EN-P with addition of $\mathrm{Al}_{2} \mathrm{O}_{3}$ shows the deposition of Nickel with small particles of Nano $\mathrm{Al}_{2} \mathrm{O}_{3}$ that contributes better resistance than sample coated with EN-P only. Moreover, the sample without coating shows the surface area totally corroded. Use of CTAB surfactant improves the wettability of coating on the substrate coating.

6) The alloy also shows excellent resistance to stress corrosion cracking (SCC) and corrosion fatigue when xamined through Vicker hardness test. The micro radial cracks observed for $\mathrm{Al}_{2} \mathrm{O}_{3}$ with Aluminum paint were fewer.

This work may be further continued in future by trying out other types of surfactants.

\section{REFERENCES}

[1] NACE, Corrosion Costs and Preventive Strategies in US, publication no. FHWA-RD-01-156, 2011.

[2] J. Breakell, Selecting a Strategy for Dealing with Accelerated Low Water Corrosion, CIRIA, London UK, 2005.

[3] J. Amera, "Influence of multiple electroless nickel coatings on beech wood: preparation and characterization," Composite Interfaces, vol. 21, no. 3, pp. 191-201, 2014

[4] F. B. Mainier, "Quality of electroless Ni-P (Nickel-Phosphorus) Coatings applied in oil production equipment with salinity," Journal of Materials Science and Chemical Engineering, vol. 1, pp. 1-8, 2013.

[5] S. Roux, "Influence of a biopolymer admixture on corrosion behavior of steel rebars in concrete," Materials and Corrosion, vol. 61, issue 12, pp. 1026-1033, 2010.

[6] Y. Riddle and C. McComas, "Advances in electroless Nickel-Boron coatings: Improvements to lubricity and wear resistance on surfaces of automotive components," SAE Technical Paper 2005-01-0615, 2005.

[7] O. J. Marie, "Method of electrodepositing a corrosion resistant nickel-chromium coating and products thereof," US3282810 A, 1996.

[8] R. Dhinakaran, R. Elansezhian, and A. Lalitha, Effect of Nano additives with Surfactant on the Surface, 1st ed. Pondicherry 605014, India: Hindawi Publishing Corporation Advances in Tribology, 2013.

[9] G. Gaillard and J. L. Bouliez, "How fusion-bonded epoxies protect pipeline: Single- and dual-layer systems," Journal of Protective Coatings and Linings, 2010.

[10] G. Mallory and J. Hajdu, American Electroplaters and Surface Finishers Society, 1990, ch. 1.

[11] R. Muraliraja, R. Elansezhian, and K. Patterson, "Optimization of reducing agent and key parameters effect on the efficiency of electroless ni-p plating by Taguchi method," Journal of Procedia Materials Science, vol. 5, pp. 2478-2486, 2014.

[12] Corrosion rate formula by General Magna Plate Corporation. [Online]. Available: http://frictioncalculator.com/corrosion-rate-formula

[13] M. F. Arenas and R. G. Reddy, "Corrosion of steel in ionic liquids," Journal of Mining and Metallurgy, vol. 39, no. 1\&2, pp. 81-91, 2003.

[14] D. K. Ward, E. M. Moore, and P. J. Hawkins, "External and internal pipeline coatings in Arabian Gulf Area," in Proc. 5th International Conference on Internal and External Protection of Pipes, Innsbruck, October 1983.

[15] E. Rasu, "Study on structural characterization of surfactants influence on electroless Ni-P deposits," Science Domain International, British Journal of Applied Science and Technology, vol. 5, pp. 1-10, 2014.

Muhammad Mumtaz Mirza is Senior Lecturer in Mechanical \& Industrial Engineering Department, Caledonian College of Engineering, Muscat, Oman._Mr Mumtaz has 21 years of industrial as well as 8 years of academic experience. His major field is CAD/CAM and design. Presently he is doing $\mathrm{PhD}$ as part time from Glasgow Caledonian University, UK. in the field of protective coatings for oil pipe lines against corrosion specially in Oman environment.

Elansezhian Rasu is Senior Lecturer (Associate Professor) in Mechanical \& Industrial Engineering Department, Caledonian College of Engineering, Muscat, Oman. Dr. Elan has done his PhD in Nano additives for protective coatings. He has almost 20 years of teaching experience. He has published 101 papers out of which 35 are referred to be from international journals. Presently he is guiding $6 \mathrm{PhD}$ students.

Anjali de Silva is currently Reader (Associate Professor) in Manufacturing Engineering at School of Engineering \& Built Environment, Glasgow Caledonian University in Scotland. She gained her BSc. (Hons) in engineering from the University of Aberdeen and her $\mathrm{PhD}$ in Mechanical Engineering from the University of Edinburgh. She has over 100 refereed publications in unconventional machining processes, sheet metal forming, composite manufacturing and condition monitoring. She is a member of the Institution of Engineers and Technicians (IET, formerly IEE) and the Academy for Production Engineering Research (CIRP). 